\title{
Fathers against Sons / Sons against Fathers: The Problem of Generations in the Early Soviet Workplace
}

\author{
Diane P. Koenker \\ University of Illinois at Urbana-Champaign
}

At the end of the 1920s, the Soviet Union underwent a series of massive and convulsive transformations that have been variously labeled the "second Russian revolution," "Stalin revolution," "cultural revolution," and "revolution from above." Among the many and complex elements of this period of revolutionary and transformatory fervor, the young communists, or Komsomol, stood out for their bold assaults on bureaucracy, on the older generation, and on the socialist status quo. Young communists responded to the party call to serve as the "light infantry" of the new drive for economic and cultural transformation, sending their shock brigades to storm the fortresses of class enemies and Soviet complacency alike. The youthful zeal of these Komsomol activists has been compared to that of youth movements in other revolutionary societies, particularly the Red Guards of the Chinese cultural revolution. ${ }^{1}$ The highly visible role of young Communists in the cultural revolution of 1928-30 seemed to vindicate a decade-long project of the Communist party to nurture, educate, and mobilize youth as the "next generation" of communism, as the key to the future of the revolution itself. Lenin himself set the tasks for youth

An early version of this paper was presented at the American Association for the Advancement of Slavic Studies annual convention in Seattle, November 1997. I gratefully acknowledge research support from the International Research and Exchanges Board, the Fulbright-Hays program of the U.S. Department of Education, the National Council for Eurasian and East European Research, and the National Endowment for the Humanities. I owe thanks also to Clare Crowston, Anne Gorsuch, Laura Phillips, William Rosenberg, Steve Smith, Mark Steinberg, Isabel Tirado, and the journal's anonymous reviewers for helpful advice and comments.

${ }^{1}$ Sheila Fitzpatrick, "Cultural Revolution as Class War," in Cultural Revolution in Russia, 1928-1931, ed. Sheila Fitzpatrick (Bloomington, Ind., 1978), p. 24. See also Hilary Pilkington, Russia's Youth and Its Culture: A Nation's Constructors and Constructed (London, 1994), pp. 58-60; Hiroaki Kuromiya, Stalin's Industrial Revolution: Politics and Workers, 1928-1932 (Cambridge, 1988), pp. 115-16, 119-20; William J. Chase, Workers, Society, and the Soviet State: Labor and Life in Moscow, 1918 1929 (Urbana, Ill., 1987), pp. 236-38; Lynne Viola, The Best Sons of the Fatherland: Workers in the Vanguard of Soviet Collectivization (New York, 1987), p. 37; Lewis H. Siegelbaum, Soviet State and Society between Revolutions, 1918-1929 (Cambridge, 1992), pp. 209-10.

[The Journal of Modern History 73 (December 2001): 781-810]

(C) 2001 by The University of Chicago. 0022-2801/2001/7304-0002\$02.00

All rights reserved. 
in 1920: "The old order has been destroyed, as it deserved to be, it has been transformed into a heap of ruins, as it deserved to be. The ground has been cleared, and on this ground the younger communist generation must build a communist society ... the generation which is now fifteen years old will see communist society, and will itself build this society. And this generation must know that the whole purpose of its life is to build communist society." 2

And yet, evidence from the ground, from the workplace rather than the Young Communist League, reveals a different scenario. Shop-floor evidence suggests that young workers themselves did not necessarily respond positively to their putative mobilization at the end of the decade, perhaps due to the treatment they had endured through the conflict of generations on the factory floor. The stagnant economy of the 1920s, with massive unemployment in many urban industries, encouraged the working-class rank and file consistently to favor seniority over honoring the promise of youth, incurring the enmity and rebellion of youth against the older generation. This article will explore the question of the mobilization of the new generation by examining relations between old and young - fathers and sons - on the shop floor in the printing industry, a highly skilled and articulate segment of the Russian workforce. In identifying a clear pattern of generational hostility among these urban workers, it will offer some alternative explanations for the phenomenon of perceived Komsomol activism in the midst of the first five-year plan and will aim to enrich our understanding of the relationship between youth, socialism, and social change in the first decades of Soviet power.

The problem of generations in the Soviet workplace lends itself to constructing multiple stories. The theme of generational conflict involves oedipal assumptions of endemic generational competition: "the hatred with which the mature of Western society regard the young is a testimony to the latter's importance, to their power potential and actual." ${ }^{3}$ A second generational story contextualizes biological generations and attends analytically to concerns about the role played by generational cohorts, generational units, and particular generational experience. ${ }^{4}$ The economic story of the 1920 s emphasizes issues

${ }^{2}$ V. I. Lenin, "The Tasks of the Youth Leagues" (speech delivered at the Third AllRussia Congress of the Russian Young Communist League, Oct. 2, 1920), in Marx, Engels, Marxism, 7th ed. (Moscow, 1965), pp. 435, 444 (emphasis mine).

${ }^{3}$ F. Musgrove, Youth and the Social Order (London, 1964), p. 10. See also Dieter Dowe, ed., Jugendprotest und Generationenkonflikt in Europa im 20. Jahrhundert: Deutschland, England, Frankreich, und Italien im Vergleich (Bonn, 1986); Alan B. Spitzer, "The Historical Problem of Generations," American Historical Review 78 (1973): 1353-85. The 1960s and 1970s saw a spate of historical studies on generation, which have tapered off as the youth-based protests of the 1960s have receded from contemporary concern.

${ }^{4}$ Karl Mannheim, "The Problem of Generations," in Essays on the Sociology of Knowledge, ed. Paul Kecskemeti (New York, 1952), pp. 302-12. On Mannheim, see Robert Wohl, The Generation of 1914 (Cambridge, Mass., 1979), pp. 73-84. 
of productivism and unemployment and highlights themes of planning, regulation, and labor market relations. The narrative of cultural revolution explores the utopian dreaming recounted by Richard Stites, the mobilization of new strata of society, and conflicts between the old and the new. The story of the creation of the new socialist personality links generational issues to the identification of good and bad social types, the upright Komsomol activists and the hooligan delinquents. ${ }^{5}$ An approach from the perspective of gender calls attention to the construction of masculinity as a corollary of the experience of maturation. The narrative of everyday life presumes not only that the workplace is an important site of power relations between employer and employee but also that the labor process as it is enacted on the shop floor, shaped by everyday cultural practices and social interactions, is a key constituent of identity formation. Above all, it is important to emphasize the multiple and ambivalent social relations that characterized this society, as class, kin, gender, cultural, political, and national identities each provided to the subjects in this study competing, overlapping, and sometimes conflicting sets of values.

Bolshevik rhetoric about youth emphasized that subgroup's potential as an agent for revolutionary change. Anne Gorsuch links the Bolsheviks' special concerns about youth with more general European ideas about biological degradation and biological regeneration, with youth seen as the malleable material with which the revolution could create new socialist men and women. ${ }^{6}$ Hilary Pilkington points out how the Bolsheviks imagined youth to be the "constructors of communism" in a socialist society, in which a conflict-free "continuity of generations" would replace the struggle between classes as the motor of history. Moreover, the process of construction would bring communism home to the new generation. The productivist ideology of Soviet socialism posited not only that participating in the manufacture of material goods was the most important duty of its citizens but also that production was the activity that could transform their lives. The production process would allow the older generation to transmit its social inheritance to the new generation and would at the same time instill in the rising generation the understanding that "the whole purpose of its life is to build communist society." Participation in production would overcome endemic generational conflict and replace such conflict with the overarching unity of class.

\footnotetext{
${ }^{5}$ Richard Stites, Revolutionary Dreams: Utopian Vision and Experimental Life in the Russian Revolution (New York, 1989).

${ }^{6}$ Anne E. Gorsuch, Youth in Revolutionary Russia: Enthusiasts, Bohemians, Delinquents (Bloomington, Ind., 2000), chap. 1.

${ }^{7}$ Lenin, p. 444; and Pilkington, pp. 44-52, 84. On the productivist ideology of Soviet trade unions, see Diane P. Koenker, "Labor Relations in Socialist Russia: Class Values and Production Values in the Printers' Union, 1917-1921," in Making Workers Soviet: Power, Class, and Identity, ed. Lewis H. Siegelbaum and Ronald Grigor Suny (Ithaca, N.Y., 1994), pp. 159-93.
} 
To explore these issues of generation and class in the 1920s, I will focus on youth in the printing industry, with particular attention to the position of the apprentice on the shop floor, both in trade-union policy and in practice. The printing trade was a quintessentially urban one, marked before the revolution by a proud sense of class consciousness and, after 1917, insistent on its central role in producing the cultural weapons for socialist transformation. This selfconsciousness of printers was extensively reflected in published materials generated at all levels of the trade's organization, from journals and reports published by central and municipal union bodies to weekly or monthly newspapers produced by printers in individual printing plants. These materials, combined with records of factory and union committee deliberations, provide a rich source base from which to analyze the position of worker youth in the early years of Soviet society. This discussion will begin with an examination of the apprentice as a social category and object of state policy, paying particular attention to the mandate of quotas for youth employment in industry. From there it will turn to a consideration of the evidence and sources, both economic and cultural, of generational hostility on the shop floor, and then it will return to a consideration of the significance of the apparent rise in youth activism at the start of the first five-year plan in 1928 and 1929.

Adolescence, it is argued, was a creation of the modern era, when youth emerged as a special period of discontinuity, a transitional category between childhood and adulthood. If Jean-Jacques Rousseau has often been credited with the invention of youth, in the nineteenth century youth became the object of concern of reformers, philanthropists, and social engineers of all stripes; but the boundaries of this focus of their concern remained fluid, overlayering psychological, customary, and legal definitions of adolescence. ${ }^{8}$ Nonetheless, to be an object of policy, youth had to be legible, in James Scott's term; ${ }^{9}$ it had to be precisely defined. Officially in the Soviet Union, a "youth" (podrostok [literally "undergrown"]) was a worker between the ages of fourteen and eighteen. Young workers between the ages of fourteen and sixteen received special attention and protection. ${ }^{10}$ For political purposes, "youth" delegates to factory committees and union congresses could be anywhere up to twenty-two years of age. ${ }^{11}$ The incompleteness of youth is conveyed by the tsarist legal term for

${ }^{8}$ See, e.g., Musgrove, p. 33; S. Allen, "Some Theoretical Problems in the Study of Youth," Sociological Review 16 (1968): 319-31; Harry Hendrick, Images of Youth: Age, Class, and the Male Youth Problem, 1880-1920 (Oxford, 1990), chap. 4; Michelle Perrot, "Worker Youth: From the Workshop to the Factory," in A History of Young People, vol. 2, Stormy Evolution to Modern Times, ed. Giovanni Levi and Jean-Claude Schmitt, trans. Carol Volk (Cambridge, Mass., 1997), pp. 66-116.

${ }^{9}$ James C. Scott, Seeing Like a State: How Certain Schemes to Improve the Human Condition Have Failed (New Haven, Conn., 1998).

${ }^{10}$ Moskovskii pechatnik 12 (Dec. 31, 1921): 10; Pechatnik 4 (March 1923): 5.

${ }^{11}$ Moskovskii gubernskii otdel soiuza rabochikh poligraficheskogo proizvodstva 
minor: the labor of maloletnie ("small in years," those under fourteen) and nesovershennoletnie ("incomplete in years," workers under seventeen) received special legislative protection. ${ }^{12}$ Throughout the 1920 s, the period covered in this article, young workers under eighteen represented a relatively small fraction of the labor force in the printing industry, never exceeding 13 percent of the whole. In 1921, at the end of the civil war, youth under eighteen accounted for only 3.6 percent of the printers' trade-union membership in Petrograd (with boys outnumbering girls two to one). In July 1922, the figure for the national union had reached 7 percent. By March 1923, the union recorded that 10.2 percent of its members were youths aged sixteen to eighteen, and another 2.6 percent were between the ages of fourteen and sixteen. ${ }^{13}$ This year, 1923 , marked the peak of the employment of teenagers in the industry. By January 1925, the proportion of youths eighteen and under had fallen to 7.9 percent, and by September 1929 the percentage of youths eighteen and under in the industry had fallen back to 2 percent. ${ }^{14}$ This proportion is thus considerably smaller than the share of another special category of workers, women, whose participation in the printing industry hovered around 25 percent and whose place in the working class received extensive attention. ${ }^{15}$ But youth attracted disproportionate attention from trade union officials and in the trade union press. While the special "women's pages" in the union journals and factory newspapers virtually disappeared after 1925 , youth pages continued to be featured as regular sections of local publications throughout the 1920 s. ${ }^{16}$

SSSR, Otchet pravleniia s 1 oktiabria 1924 g. po 1 oktiabria 1925 g. (Moscow, 1925), p. 11 .

${ }^{12}$ V1. Iul. Gessen, Istoriia zakonodatel'stva o trude rabochei molodezhi v Rossii (Leningrad, 1927), p. 74.

${ }^{13}$ Since union membership was virtually automatic for Soviet workers in the 1920s, figures for the industry and for union membership can be taken as approximate substitutes for one another. Altogether, 30 percent of union members were under the age of twenty-three. Petrograd: Tsentral'nyi gosudarstvennyi arkhiv Sankt Peterburga (TsGA SPb), f. 4804, op. 5, d. 71, 1.4 (August 1921 union meeting); Trud (Sept. 19, 1922), p. 5; Pechatnik 4 (March 1923): 5-6.

${ }^{14}$ Pechatnik 3 (January 1930): 11.

${ }^{15}$ Diane P. Koenker, "Men against Women on the Shop Floor in Early Soviet Russia: Gender and Class in the Socialist Workplace," American Historical Review 100 (1995): $1438-64$.

${ }^{16}$ References to factory newspapers are based on my reading of the newspapers for six selected enterprises, three in Moscow and three in Leningrad. They are, for Moscow: Krasnyi proletarii (organ of the Krasnyi Proletarii [Twentieth State] Printshop (192330); Nasha zhizn' (organ of the Sixteenth State Printshop) (1923-30); Zhizn' pechatnika (organ of the First Model State Printshop) (1923-30); and for Leningrad: Iskry (organ of the Evgeniia Sokolova [Twenty-Sixth State] Printshop) (1925-30); Pechatnyi dvor (organ of the Pechatnyi Dvor Printshop) (1924-30); Zorkii glaz (later Leningradskii Pravdist) (organ of the Leningradskaia Pravda [Fourteenth State] Printshop) (1924-30). The absence of uniformity in these locally produced publications gives 
As a skilled trade, the printing industry had always replenished its ranks by means of apprenticeship, which served both as a category and a process. In the factory hierarchy, the apprentice occupied the lowest position, signified by less-than-subsistence wages. A range of shop-floor practices that ritualized this utter subordination of apprentices had become an important part of printing worker culture, and through these rituals of subordination, masters and later trade union members inscribed roles and identities for young males. ${ }^{17}$ The apprenticeship thus served as a mechanism for elders-the metaphoric fathers - to imprint their values and authority on the sons, to channel and contain potentially disruptive and dysfunctional expressions of autonomy. Apprenticeship also provided a standard against which adult workers could assess their own manhood. Skill and manliness were closely linked in the identity of Russian printers. The central role played by drink, for example, in marking passages from beginner to competent worker, and the close relationship between drink and masculinity, as Laura Phillips has argued, underscores the perception that apprentices began their working lives as inferior and nonmasculine beings. ${ }^{18}$ An apprentice who later became a socialist factory director recounted the process this way: "He grew up, became manly (vyros, vosmuzhal)." 19 Ava Baron writes of U.S. printers, "Workingmen contrasted themselves to these boys as a measure of their manliness; boys were what workingmen had once been, what they were not now, and what they feared resembling. ${ }^{20}$ But however detestable, the boy apprentice of today would become the skilled male worker of the future: in serving out the apprenticeship process, boys became men. ${ }^{21}$ And in order to build communism, sons needed to grow up to become

them a special authenticity and makes them valuable sources for local experience. The contributors to these newspapers surely faced official censorship and they exercised their own self-censorship, but in varying degrees and ways.

${ }^{17}$ See, e.g., discussions of prival'naia - drinking rituals - in Laura L. Phillips, Bolsheviks and the Bottle: Drink and Worker Culture in St. Petersburg, 1900-1929 (DeKalb, Ill., 2000), pp. 50-56; and Mark D. Steinberg, Moral Communities: The Culture of Class Relations in the Russian Printing Industry, 1867-1907 (Berkeley, Calif., 1992), pp. 70-74.

${ }^{18}$ Steinberg, pp. 68-74; Phillips, pp. 31-36; Koenker, "Men against Women."

${ }^{19}$ Moskovskii pechatnik 36-37 (September 1926): 17.

${ }^{20}$ Ava Baron, "An 'Other' Side of Gender Antagonism at Work: Men, Boys, and the Remasculinization of Printers' Work, 1830-1920," in Work Engendered: Toward a New History of American Labor, ed. Ava Baron (Ithaca, N.Y., 1993), p. 49. On the relationship between skill and masculinity (but not in terms of apprenticeship), see Cynthia Cockburn, Brothers: Male Dominance and Technological Change (London, 1983), pp. 132-40.

${ }^{21}$ In complaining that apprentices were not given meaningful work, one factory newspaper correspondent wrote that whoever was distributing jobs had forgotten that he would retire and would be replaced by the apprentices he now ignored: Nasha zhizn' 43 (Oct. 22, 1925): 2. 
proper fathers, with the correct socialist values that they in turn could pass on to their sons. Thus the trade union recognized the need to temper its rituals of subordination in order to minimize the risk of open rebellion. The future of the socialist project depended on continuity, not conflict, of generations.

Nonetheless, practical training had always involved rituals of subordination, and the socialist ownership of the means of production did not automatically transform the traditions of shop-floor culture. In the prerevolutionary era, a young boy would typically sign up with a shop or a master around the age of twelve, and for a nominal wage he would spend the next four years in training. Masters would impart their craft to their successors, but usually in ways that emphasized the power held by the masters to determine the fate of their pupils. Frequently, this translated into incomplete, superficial training and routine abuse of the apprentice's dependent position. Worries about a perceived "apprenticeship crisis" were a common theme in late nineteenth-century Europe, and Russia was no exception. ${ }^{22}$ Much ink was spilled in the printing trade press before 1914 about the alleged decline in the quality of the boys who were hired and the "training" they received. Many apprentices were barely literate and could not therefore read the texts they were learning to set in type. Over and over again in their memoirs, apprentices in the prerevolutionary period reminded readers of their distance from the real world of the trade they sought to learn: instead, they were called upon by bosses and senior workers alike to run errands (typically to the vodka shop), to sort spilled type, to assist the owner with domestic tasks, including acting as nanny for his children, and generally to provide unskilled labor for the enterprise. Verbal and physical abuse also seemed to be the norm, judging by adult printers' recollections. Given this indifferent instruction, only lucky and talented apprentices would manage to acquire the needed skills to become fully fledged craftsmen. Toward the end of the nineteenth century and continuing into the twentieth, especially after the 1905 revolution, labor activists attempted to develop more systematic training for apprentices through evening schools and special courses. But the majority of the adult printers who set the standards in the socialist print shops of the 1920s had presumably paid their apprenticeship dues in the old style, and this surely affected their attitude toward training their own replacements. ${ }^{23}$ "The conditions of this apprenticeship," recalled the trade union newspaper

${ }^{22}$ See Hendrick (n. 8 above), chap. 3; Perrot (n. 8 above), pp. 88-93.

${ }^{23}$ Istoriia Leningradskogo soiuza rabochikh poligraficheskogo proizvodstva (Leningrad, 1925), 1:59-76; Steinberg, pp. 68-74; A. Svavitskii and V. V. Sher, Ocherk polozheniia rabochikh pechatnogo dela $v$ Moskve (po dannym ankety, proizvedennoi O-vom rabochikh graficheskikh iskusstv v 1907 godu) (St. Petersburg, 1909), pp. 914, 43-49; Ivan Pavlov, Zhizn' russkogo gravera, ed. M. P. Sokol'nikov (Moscow, 1963), pp. 40-43; E. A. Vechtomova, Zdes' pechatalas' "Pravda” (Leningrad, 1969), p. 22. 
Trud, created a "dismal picture of the past which can never be forgotten by those who passed through this oppressive [tiazheluiu] schooling." 24

How would socialism reform this once oppressive process? Soviet printers who looked back upon their rude years of training frequently blamed the economics of capitalism: boy printers challenged adults' livelihood because their cost was so low. ${ }^{25}$ Socialism would eliminate the competitiveness of market relations. Generations that worked together instead of competing with one another could impart a work ethic and socialist values in a less antagonistic way than under the craft traditions of capitalism. Clearly one key to promoting a socialist continuity of generations was the way in which skilled labor was reproduced. The years of Soviet apprenticeship afforded a crucial opportunity for senior workers to train the "next generation" in terms of both skills and social behavior. Training the next "shift" [smena] thus occupied a permanent and important place on the agenda of the Soviet trade union of printers, which embraced the regime's dedication to modernization, to education, to changing consciousness and values, and to production. ${ }^{26}$ Affirming its solicitude for the fragility of youth, the printers' union, following national norms, decreed in 1922 that no worker under the age of sixteen could be employed for more than four hours each day, with the rest of the day devoted to study. Workers between sixteen and eighteen were restricted to a six-hour work day. Both groups were to be paid at an eight-hour rate for the pay grade to which they were assigned: typically, young workers and apprentices earned at no higher than the third level (razriadka) of the twelve-grade pay scale. ${ }^{27}$ By union rules, youths and apprentices would continue to receive a (low) fixed salary and were prohibited from more lucrative piece work even after piece rates became the industry standard in $1925-26 .{ }^{28}$ All young people received special attention to their

${ }^{24}$ Trud (Oct. 10, 1922), p. 4.

${ }^{25}$ Moskovskii pechatnik 17 (April 1926): 2; Istoriia Leningradskogo soiuza, p. 60.

${ }^{26}$ The basic decision on professional training was a Sovnarkom decree of June 20 , 1919, creating a section of professional-technical education under the People's Commissariat of Education; M. M. Kucherenko, Molodoe pokolenie rabochego klassa SSSR (Moscow, 1979), p. 53.

${ }^{27}$ Trud (July 23, 1922), p. 3 (report on a youth conference where the implementation of the policy is discussed); see also Trud (Sept. 19, 1922), p. 5; Pravda (Oct. 26, 1922), p. 4; Pechatnik 4 (March 1923): 7. The restricted work day at full pay was endorsed by the Fourth Komsomol Congress in September 1921; see Ralph Talcott Fisher, Jr., Pattern for Soviet Youth: A Study of the Congresses of the Komsomol, 1918-1954 (New York, 1959), p. 90.

${ }^{28}$ The third Moscow province conference of young printers, held on October 15, 1923, also recorded opposition to piece rates for young workers (Moskovskii pechatnik 12 [Oct. 29, 1923]: 21. Some compromises were made in 1925, permitting the most advanced apprentices to share in "collective piece rates" (teams who worked collectively to earn a rate based on output) (Pechatnik 12 [June 15, 1925]: 6). Not until 1928 
health, their morals, their living conditions, and, through the Komsomol, their political education.

The union also sought through its system of vocational education to transform the relationship between old and young and to affirm the importance of youth as the builders of communism. To replace the old haphazard system of training, in which apprentices learned only by observing or by becoming a favorite of a senior worker who would then impart his skills with care and attention, the socialist union rationalized occupational education. The printers' union sponsored three types of training for its apprentices: individual training, in which a young printer worked in a regular shop under the supervision of a skilled senior worker [master or instruktor]: brigade apprenticeship, in which teams of ten to fifteen trainees would be assigned to a designated part of a normal printing shop, under the supervision of a specially appointed teacher; ${ }^{29}$ and, finally, the factory training school (fabrichno-zavodskoe uchilishche, fabzavuch, or FZU shkola [FZU school]). The FZU school could be either a separate department within an existing shop (something possible in the printing industry only in the largest enterprises) or a separate enterprise altogether. Each form of training carried different costs and benefits, both economic and social. Union educators argued that only the FZU school provided serious education and training. The FZU schools located inside existing printshops often failed to privilege investment (training) over immediate value to the enterprise (output now), leading to calls for the complete centralization of formal vocational instruction. ${ }^{30}$ But this centralized FZU option was expensive. Resources available for training were never adequate, and they fluctuated with changes in the labor market and the demand for printed goods. Furthermore, the FZU school, whether attached to an existing shop or located in an enterprise of its own, carried risks: students there were isolated from mainstream shop-floor culture and might improperly develop their own deformed work culture. The undis-

was the issue reconsidered (Pechatnik 26 [Sept. 12, 1928]: 19 [Moscow city youth conference]).

${ }^{29}$ Pechatnik 15 (Dec. 30, 1923): 12. On the older methods, see Pavlov, p. 42; Pechatnik 25 (Sept. 5, 1927): 25.

${ }^{30}$ Trud (July 23, 1922), p. 3. In July 1922, 50 percent of the union's youths were assigned to independent FZU schools; the remainder worked in production, either directly on the shop floor or in factory-based schools (Trud [Sept. 19, 1922], 5). The proportion of formally trained youth was higher in the two biggest cities, where economies of scale could justify special schools. In Voronezh, on the other hand, only 37 percent of the province's apprentice printers studied in an FZU school in 1923-24 (Otchet o deiatel'nosti Pravleniia Voronezhskogo Gubotdela SRPP s 1/VI 23 g. po 1/ $X 24 \mathrm{~g}$. [Voronezh, 1924], p. 26). And as unemployment in the industry reduced the overall number of apprentices in the second half of the decade, by 1928 only 30 percent of apprentices were trained in the still-preferred FZU schools (Pechatnik 18 [June 22, 1928]: 7). 
ciplined youth of the next generation could be better monitored and controlled under the direct and subordinating eye of masters on the shop floor itself. Separate training sites also ran the risk of marginalizing young workers, and directors and students of the FZU schools regularly had to implore the union to devote more resources and attention to the needs of their students. ${ }^{31}$

Individual and brigade training, carried out on the job in the course of the regular production activities of the enterprise, involved the apprentice directly in the life of the shop floor. Such training was less expensive than education in the FZU schools, since it was conducted with the resources at hand. Such training also offered better opportunities for the social and political integration of worker youth into the time-honored practices of the craft. But trade union officials considered individual apprenticeship to be the most risky form of training. ${ }^{32}$ On-the-job training continued to apply the stigma of the apprentice as the lowest creature on the evolutionary ladder of factory status, and apprentices would wonder publicly about whether studying the craft in the "real world" compensated for the insults, abuse, and indifference they endured. One commission investigating apprenticeship in Leningrad found that "while all meetings of bureaus and plenums speak about the need to help the youth in their everyday work, we see that all this remains mere talk. ... Workers must actually help the young in their tasks, and not get off with loud words at meetings, which are forgotten as soon as they return to their workshops." 33 Nor did the practical shop-floor training provide the same level of theoretical preparation thought necessary for the next generation. ${ }^{34}$

Left to their own devices, it turned out that adult workers were extremely reluctant to admit apprentices to their enterprises at all. Socialist promises notwithstanding, jobs were scarce in the reviving Soviet economy at the end of the Russian civil war, as Red Army soldiers returned from service and workers who had fled the starving cities left their rural refuges to claim their

${ }^{31}$ For example, Moskovskii pechatnik 12 (Dec. 31, 1921): 11; ibid. 18 (Feb. 27, 1924): 21; Pechatnik 9-10 (June 1, 1924): 16; ibid. 13 (July 15, 1924): 8; Moskovskii pechatnik 33 (Nov. 7, 1924): 12; ibid. 2 (Jan. 15, 1925): 4. Sheila Fitzpatrick writes that individual-brigade training, rather than the FZU school, was the form preferred by the Supreme Economic Council throughout NEP, but the printing industry, by contrast, explicitly favored the FZU school; see Sheila Fitzpatrick, Education and Social Mobility in the Soviet Union 1921-1934 (Cambridge, 1979), pp. 198-99.

${ }^{32}$ For example, the letter from a former director of a prerevolutionary school, in Moskovskii pechatnik 7 (Oct. 30, 1922): 12.

${ }^{33}$ Zorkii glaz (Feb. 23, 1929). Emphasis in original.

${ }^{34}$ See, e.g., Moskovskii pechatnik 15 (April 23, 1925): 11; Pechatnik 9 (May 1, 1925): 19; Moskovskii pechatnik 18 (May 8, 1925): 11; Pechatnik 15 (Dec. 30, 1923): 12. Complaints about individual training run throughout the factory newspapers: Iskry (January 1926); Pechatnyi dvor (Oct. 25, 1928), p. 3; Leningradskii pravdist (June 3, 1930); Krasnyi proletarii (Feb. 17, 1930). 
former jobs. The market still discriminated against training unskilled youth, who were seen as "nonproductive ballast." ${ }^{35}$ Consequently, as the cornerstone of its industrial youth policy, the Soviet regime intervened in the market and announced in May 1922 the introduction of a quota system for the employment of young people in industry. ${ }^{36}$ The quota (bronia) stipulated that in the printing industry 13 percent of the labor force would be youths, and 25 percent of the youths would be female. This quota soon became the union's albatross as the ongoing industrial crisis in printing kept thousands of skilled printers out of work and idle in the labor exchange queue. Some veteran printers would support this affirmative action policy in the same spirit as the union leadership that implemented it, in order to guarantee that the craft would continue to exist. They believed in the model of continuity of generations. But for many others, this privileged place for youth seemed a pointless luxury, an insulting loss of control over their trade. The struggle over the quota thus offers an especially useful episode for understanding the values and conflicts between generations.

Although the quota policy represented a national initiative, the youth policy of the printers' trade union had roots also in the bitter political struggle between Mensheviks and Bolsheviks for control of the union. During the years of the civil war the two factions had waged a fierce battle for hegemony within the union, and gaining the allegiance of the feisty young printers in this climate seemed an appropriate strategy for both social-democratic parties. Rival youth clubs competed for members. The Society for the Intellectual and Physical Development of Young Printers, the Menshevik group, offered its members a rich menu of cultural fare, even in hungry 1919, and the Menshevik union leaders reported with satisfaction that young printers "united and unanimously" defended the Menshevik opposition at a Moscow city youth conference. The red union countered with its own club, with an attractive snack bar. Young workers did go for the food, admitted the Menshevik union, but soon returned to the Menshevik club because of its superior cultural offerings. ${ }^{37}$ The Men-

${ }^{35}$ Moskovskii pechatnik 10 (Nov. 1, 1921): 5.

${ }^{36}$ Kucherenko (n. 26 above), p. 61. The law, passed by the Central Executive Committee of Soviets on May 2, 1922, "On establishing a specific minimum number of youths in enterprises," listed specific quotas for each of thirty-three branches of industry, ranging from 2 to 13 percent (Sobranie uzakonenii RSFSR, 1922, no. 39, st. 447). I have been unable to determine how the precise quota for printing was established. [E. H. Carr calls the term for the quota, bronia, an "ironclad minimum," mistakenly, I believe, deriving the term bronia from the verb bronirovát' (to armor) rather than from bronírovat' (to reserve, to book); see E. H. Carr, Socialism in One Country 1924-1926 (London, 1958), 1:370.]

${ }^{37}$ Gosudarstvennyi arkhiv Rossiiskoi Federatsii (GARF), f. 5461, op. 1, d. 29 (protocols of the Moscow printers' trade union, 1919), 1l. 27, 27ob.; Pechatnik 6 (1918): 
sheviks assigned a special instructor to organize young printers and appealed for their votes in the spring 1920 election to the Moscow union's board of directors by urging them to reject the Bolsheviks' crass material promises of "jerseys and sandwiches." 38 Despite redoubled Bolshevik efforts to organize the printer youth, Menshevik influence persisted among young printers well into $1922 .{ }^{39}$

The Mensheviks must have played successfully on the dismal economic and social status of young printers, and the Menshevik claim that the Komsomol was worthless in defending the interests of youth struck a responsive chord with the majority of nonparty worker youth. ${ }^{40}$ The second Moscow youth conference in July 1922 emphasized the goal of a six-hour work day at eight hours' pay and called for a quota of young printers in the industry, so that the youth would not be completely victimized by the continuing cutbacks in the printing labor force. ${ }^{41}$ The Communist leadership of the printers' union was slow to respond, but eventually it moved to "disinfect" the so-called conservatism of nonparty youth by addressing their material concerns. Although the national decree on an industrial youth quota was adopted in May, it was not until September 1922 that the union's central committee announced that, henceforth, 13 percent of spots in the union would be reserved for youth. ${ }^{42}$ The union also began to organize special youth sections in its clubs, and for the summer 1922 elections to factory committees it stipulated that youth should each be given a guaranteed place on every factory committee. Women, another underrepresented group in industry, received the same benefit. ${ }^{43}$

To some extent, the move toward incorporating youth and women can be read as an attempt to fulfill the socialist promise of full citizenship for every

13; Pravda (Oct. 3, 1919), p. 2; ibid. (June 25, 1920), p. 2. Most of this story comes from the side of the Bolsheviks. The Menshevik union organization, harassed and then working underground, produced a much smaller body of printed and archival material. Surviving minutes of the meetings of the oppositional printers' council of representatives (sovet upolnomochennykh) provide much information on the political struggle, but less specifically about the role played by youth (GARF, f. 5461, op. 1, d. 30).

${ }^{38}$ Pravda (June 25, 1920), p. 2.

${ }^{39}$ Pravda (June 27, 1920), p. 4; Moskovskii pechatnik 2 (Feb. 15, 1921): 11; ibid. 4 (July 1, 1922): 15: the Thirty-first and Fifth Moscow Print Shops were only just emerging from the influence of "little Menshevichki" and "visiting [gastrolery] Mensheviks."

${ }^{40}$ Vserossiiskii pechatnik 8 (23) (August 1922): 9.

${ }^{41}$ Trud (July 23, 1922), p. 3; ibid. (Sept. 19, 1922), p. 5.

${ }^{42}$ Trud (Sept. 19, 1922), p. 5; Pravda (Oct. 26, 1922), p. 4.

${ }^{43}$ These instructions were discussed at a general meeting of workers and employees of Petrograd's Fourteenth State Print Shop, July 14, 1922 (TsGA SPb, f. 4804, op. 6, d. 34 [Leningrad branch of the union of printers, protocols of general factory meetings], 1. 123ob.). On the incorporation of women workers, see Koenker, "Men against Women." 
worker. Such ideological motivation surely provided a justification for the policies of affirmative action, but given the context of their adoption I would argue that the central union leadership (and these decisions came from higher up than the printers' union) adopted these policies to co-opt youth and women, whose threat to the socialist experiment might take on different forms (youth destroying it with their undisciplined rowdyism or tilting it toward Menshevism, women dragging it down with their conservatism). Members of both alien generation and alien gender needed to be convinced that Soviet power protected their interests. The next generation needed to be coddled and encouraged to keep on the right ideological path to maturity. ${ }^{44}$

Economic realities as well as generational hostility or indifference added to the pressures on young printers. Unemployment in the printing industry had climbed steadily from 1921 until 1924, when the momentary convergence of industrial recovery and extensive job sharing (shortened work weeks and work days) created a brief interlude of full employment for the skilled workers in the trade. But unemployment began to rise again dramatically in the industry in late 1925, and by the start of 1927 unemployment among printers stood at 18 percent of union members. ${ }^{45}$ Already by the end of 1924, a looming oversupply of workers had reduced the scale of apprenticeship: Moscow was forced to cut its training back to a single central school, named for the Moscow union leader Aleksandr Borshchevskii. ${ }^{46}$ Whereas in 1922, 50 percent of the union's youth studied in FZU schools, by 1928 only 30 percent of a much smaller number of youths overall received their training in formal schools. As industrywide unemployment transformed printers' expectations and attitudes about the socialist future, the ambivalence toward apprentices and youth more generally now acquired a third dimension. Apprentices were already the source of the next generation and at the same time the ontogenetic inferiors by which adult printers measured their own maturity (and masculinity). But by 1925 their low productivity and high costs were seen to exacerbate the already dismal state of the industry.

The greatest threat to the principle of a youth quota continued to be unemployment in the industry. Petrograd suffered much more severely than Mos-

${ }^{44}$ Lev Trotskii, always popular with young workers and young people, had to cajole youth in 1923 to accept "small deeds" instead of civil war heroics; see "Youth and the Phase of Petty Jobs," in Problems of Everyday Life (New York, 1973), pp. 97-104.

${ }^{45}$ Moskovskii pechatnik 18 (Feb. 27, 1924): 8-9; GARF, f. 5525, op. 6, d. 71, 1. 154 (Leningrad pravlenie meeting, July 15, 1924); Pechatnik 17 (Sept. 15, 1924): 10; Pravda (March 31, 1927), p. 4; Trud (Sept. 8, 1927), p. 3; Otchet Leningradskogo oblastnogo otdela Soiuza rabochikh poligraficheskogo proizvodstva SSSR s 1-go oktiabria 1927 g. po 1-e oktiabria 1929 g. (Leningrad, 1929), p. 5.

${ }^{46}$ Stenograficheskii otchet $V S^{\prime \prime}$ ezda soiuza rabochikh poligraficheskogo proizvodstva SSSR. 20-24 dekabria 1924 g. (Moscow, 1925), p. 319. 
cow as the demand for printed books and materials shrank in 1924 and 1925 and as the new Soviet capital generated the lion's share of printing business. Preserving the youth quota led to a pattern in which the "reserved" youth, once trained, were denied full-time jobs in the industry-because there was not enough work to sustain additional workers at adult pay rates. The graduated apprentices, having reached only the threshold of skill, imposed an unacceptable expense on their enterprises, who thus fired the newly fledged workers while accepting new apprentices - at the low apprentice rate of pay - to fulfill the youth quota requirement. ${ }^{47}$ The 13 percent target proved difficult to meet in any case: the union interpreted the government's ruling to include only skilled workers, requiring fewer young workers to fill the quota. Even allowing for variations by region, trade union officials generally admitted that the real share of youth in printing production was lower than 13 percent. ${ }^{48}$

Moreover, the distribution of reserved youth by printing departments did not correspond to the structure or needs of the industry. Cultural preferences dominated over economic rationality. New workers flocked to the cleaner and higher-status branches of the trade, typesetting and binding. Typesetters, who represented 14 percent of the printing industry, accounted for 43 percent of the apprentices; binders represented 11 percent of the industry but 25 percent of the apprentices. (Binding was increasingly seen as a "female" trade: this figure reinforces indications that girl apprentices were channeled into the traditional female occupations.) The remaining 55 percent of the industry practiced crafts (press work, lithography, typecasting) that only 6 percent of the next generation was learning. ${ }^{49}$ By the end of 1924 , then, it became clear that the policy of the quota was going to lead to major complications when the trained youth were ready to be loosed on the already saturated print shops. Suggestions to reduce the quota began to be heard at union congresses in late 1924: the union's youth organizer, Grigorii I. Barenboim, suggested a new limit of 7 percent, but a formal proposal to lower the youth quota at the 1924 union congress - which would have meant to violate the policy of the central government-went down to defeat by a vote of ninety-four to sixty-four. ${ }^{50}$ This split vote was a remarkable division of opinion in an era in which socialist

${ }^{47}$ Moskovskii pechatnik 13 (April 6, 1925): 12; ibid. 46 (Nov. 21, 1925): 10.

${ }^{48}$ Pechatnik 9 (August 1923): 6; Moskovskii pechatnik 35 (Dec. 20, 1924): 1-2.

${ }^{49}$ Moskovskii pechatnik 35 (Dec. 20, 1924): 2; Pechatnik 16 (Aug. 15, 1925): 3.

${ }^{50}$ Moskovskii pechatnik 35 (Dec. 20, 1924): 2; the December 1924 sixth Leningrad province congress and Moscow sixth congress also discussed the problem (TsGA SPb, f. 4804, op. 8, d. 56, 1. 11; VI Moskovskii Gubs"ezd rabochikh poligraficheskogo proizvodstva 23-26 oktiabria $1924 \mathrm{~g}$. [Moscow, 1924], pp. 26-30). The figures cited in the Moskovskii pechatnik article became the basis for a debate on the quota at the union's fifth national congress, December 20-24, 1924 (Stenograficheskii otchet V s"ezda, pp. $112,123-24,279-80,319-20)$. 
unanimity was already the order of the day, and thus testifies to the passion with which the printers' union confronted the challenge posed by preparing their successors. For the time being, the union deferred its desire to protect its control over the trade and accepted the ideological dictates of the regime.

Nonetheless, within a year the union had unilaterally taken action to limit the influx of new workers: the union central committee's May 1925 plenum ruled that the quota would henceforth be 10 percent and that apprentices would no longer be recruited from among seventeen- and eighteen-year-olds, since the law required them to be graduated into the workforce as soon as they reached nineteen. By recruiting younger apprentices, youth could be kept in training and out of the adult workforce longer, thus reducing the problem of the oversupply of skilled labor. ${ }^{51}$ Such reforms failed to stem the hemorrhage of unemployable workers, however. By 1926, print-shop managers were demanding that the quota be reduced to 9 percent and that the intake of apprentices immediately be halted. Union activists from the shop floor still insisted that the union think ahead, that a new generation would eventually be needed; but in short-term reality, even skilled adult workers could not find jobs, and cutting back on the costly training of apprentices seemed to offer an immediate solution to the unemployment crisis. The union announced in mid-1926 that no new apprentices would be taken on for that autumn. ${ }^{52}$ By 1928, while still seeking to address the problem of chronic unemployment, the union had begun to change the entire format of trade education: rather than preparing all-around skilled workers, apprentice schools would now train narrow specialists. This would shorten the training period and allow the union to adjust more quickly to the changing demands of the industry. Thus, "scientifically," the union calculated that a new youth quota of 6 percent, properly allocated among the subspecialties of the industry, would meet future needs for replacement workers. ${ }^{53}$

The formal decisions and discussions about the quota at union congresses impart a bland institutional patina to the fact of pervasive conflict between generations on access to jobs in the printing industry. (Congress delegates were

${ }^{51}$ Pechatnik 10 (May 15, 1925): 2; ibid. 16 (Aug. 15, 1925): 2; ibid. 17 (Sept. 1, 1925): 13.

${ }^{52}$ Moskovskii pechatnik 36-37 (September 1926): 7; ibid. $28-29$ (July 1926): 3; discussion at the seventh Leningrad province congress, March 1926 (TsGA SPb, f. 4804, op. 10, d. 4, 11. 410, 425-26, 456, 512-13, 529); Pechatnik 50-51 (Dec. 20, 1926): 6-18, which extracts from the stenographic record of the sixth national congress. The full report is in GARF, f. 5525, op. 8, d. 1.

${ }^{53}$ Pechatnik 7-8 (March 8, 1928): 32-33. For consideration of training regimens more broadly, see Kendall E. Bailes, Technology and Society under Lenin and Stalin: Origins of the Soviet Technical Intelligentsia, 1917-1941 (Princeton, N. J., 1978), chap. 7; and Fitzpatrick, Education and Social Mobility, chap. 9. 
always congratulated for being "businesslike," and the unruly conferences of the unemployed invariably received censure from union officials.) In addition to reports of specific instances of conflict between young and old, union officials constantly acknowledged their members' "hatred toward the young generation." ${ }^{54}$ Workers at the printshop of Moscow's musical publishing house claimed that to implement the union's quota was "cowardice": they refused to make way for youth. ${ }^{55} \mathrm{~A}$ union youth specialist, L. Shekhmeister, felt compelled to explain to union members in 1927 that the recruitment of apprentices would be limited and that it would not proceed at the expense of adult workers. Therefore, he reminded workers that they should treat the recruits with a friendly (druzheliubnoe) attitude. ${ }^{56}$ The marginalization of youth was captured in an entry in the "Printers' Encyclopedia" on the union journal's humor page in 1928: "Apprentice: a person for whom the print shop has become an impregnable fortress. Access to it is possible only under cover of the quota." ${ }^{7}$

Economic pressures reinforced culturally rooted hostility that contributed to the sense of generational struggle on the shop floor. Apprentices at the "Zhirkost" printshop in Moscow complained that the factory ignored their training, "but in answer to our question - when will they teach us? - here is the answer: you are not yet eighteen and you can work only six hours, I won't waste a press on you." Economic efficiency clearly played a role here, but the weight of tradition was also strong even in this case: foremen and instructors continued to base their pedagogical styles on the dominant model of their own experiences, the autocratic master craftsman. "We were beaten, and so we too will beat." 58 This worker-correspondent called on the director to train his workers in the new way, not "in the way he was taught." ${ }^{59}$ A futuristic feuilleton in the union journal in 1927 reminded readers of the bad old days (along with offering a pointed commentary about Soviet society): in August 1949, dear Grishka is being feted by his family upon the completion of his training. One of the family's guests offers a friendly examination of how well he has learned his trade:

"Suppose you are a master-craftsman or director, and you go to the shop. What is the first thing you will do?"

"Heap obscenities on the apprentices."

"Very good discipline. What next?"

${ }^{54}$ Moskovskii pechatnik 17 (April 1926): 2.

${ }_{55}$ Pechatnik 4 (March 1923): 22.

${ }^{56}$ Pechatnik 21 (July 25, 1927): 5.

${ }^{57}$ Pechatnik 23 (Aug. 15, 1928): 26.

${ }^{58}$ Istoriia Leningradskogo soiuza (n. 23 above), p. 62.

${ }^{59}$ Moskovskii pechatnik 30-31 (Aug. 12, 1925): 14. 


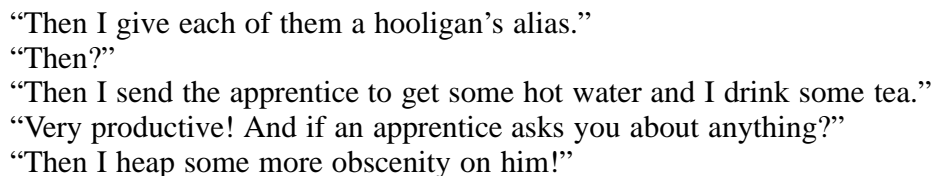

Finally, after the seventeenth such question, the family friend reassures the distraught parents that their Grishka will not become a typesetter after all; with the swearing skills and the authoritarianism he has learned, he is now fully qualified to become a militiaman. ${ }^{60}$ In the mid-1920s, the socialist ideal of generational harmony had yet to overcome the more powerful sense of generational rivalry.

Was it their own remembered experience of bygone capitalism that convinced shop administrators of the idleness of apprentices, or was it the perceived reality of the socialist shop floor? Some argued that socialism had made a negative contribution to the training of the next generation. Adults accused apprentices of being indifferent to training (in many of the same terms that were applied to adult women). Good-for-nothing trainees knew that the law prohibited their firing before the completion of their training, and so they felt invulnerable to discipline; other apprentices had entered the industry not out of any desire or aptitude but because their fathers had arranged their positions. Another part of the apprentice problem was an automatic promotion in rank every six months, providing the pupils with no incentive to apply themselves to their training. ${ }^{61}$ Young printers' indifference to acquiring skills thus translated into rude and undisciplined behavior on the shop floor, for which they often sought immunity on account of their special status as the "next generation." Youths and apprentices were causing serious problems in Petrograd print shops, agreed the Communist party cell at the Fourteenth State Printshop; they

${ }^{60}$ Pechatnik 29-30 (Oct. 25, 1927): 39. The editor explained that Ivan Osipovich Vanko, the man Grishka names as his teacher, was notorious for the behavior described in the feuilleton. The record contains many references to old-style training "as personal errand boys for the master" (Zhizn' pechatnika [March 14, 1923]); giving the master a bottle after payday (Moskovskii pechatnik 15 [Jan. 7, 1924]: 16). For an analysis of swearing in Russian working-class culture, see S. A. Smith, "The Social Meanings of Swearing: Workers and Bad Language in Late Imperial and Early Soviet Russia," Past and Present 160 (1998): 167-202.

${ }^{61}$ Tsentral'nyi gosudarstvennyi arkhiv Moskovskoi oblasti (TsGAMO), f. 699, op. 1, d. 570 (factory committee minutes from the Sixteenth State Print Shop, March 21, 1924), 1. 40; Moskovskii pechatnik 15 (Jan. 7, 1924): 17. It was "not true" that youth did not want to learn, one specialist was quoted as saying about the school at the Twentieth Print Shop (Moskovskii pechatnik 15 [April 23, 1925]: 11; ibid. 4-5 [January 1926]: 9; Pechatnik 29 [July 17, 1926]: 13). Other examples can be found in Krasnyi proletarii (Aug. 26, 1926); ibid. (Sept. 4, 1926); Iskry (Jan. 15, 1929); Leningradskii pravdist (Dec. 8, 1930). 
gathered in groups and made trouble, they flagrantly neglected their work. ${ }^{62}$ The emphasis here is on "flagrant," unlike the more subtle forms of work evasion that even adult printers were known to employ. Reflecting a growing concern in Soviet society about social deviancy, the so-called hooligan behavior of printer youth included absenteeism, tardiness, loud and rowdy behavior, even fighting, and a rejection of all criticism. ${ }^{63}$ Hooligan jargon fostered nicknames, "aliases," that further distinguished the unruly minority from the respectable mainstream, and printing apprentices took pride in their own "hooligan's alias" of "factory rabbits" (fabzaichat), a pun on the term for the FZU school, fabzavuch. In the premier training school in the country, Moscow's Borshchevskii FZU school, the director ruefully admitted that "we do have hooligans, our school graduates hooligans of the highest grade." ${ }^{64}$ It was difficult to discipline youth, explained the chairman of the trade union, Nikolai Derbyshev, because responsible adults could not communicate with them: "That language of youth, it is a completely different [drugoi] language." 65 Whether they liked it or not, affirmed a report to the union's central committee presidium in May 1929, there still existed doubt about the strength and the knowledge of youth. ${ }^{66}$ The cultural divide between generations, as perceived from the top down and reinforced by the scarcity of positions, thus remained a serious impediment to socialist unity.

The apprentices also saw the relations with their elders through the lens of generational rivalry. They complained that their teachers were too strict, too demanding, that they despised them just because they were young. Young printers chafed at the disrespect shown to them, ${ }^{67}$ and apprentices at the Leningrad Pravda printshop adapted the well-known song of a civil war hero, the "Budennyi March," to vocalize their plight:

${ }^{62}$ Tsentral'nyi gosudarstvennyi arkhiv istoriko-politicheskikh dokumentov, f. 435, op. 1, d. 29 (protocols of general Communist party meetings in Petrograd enterprises, 1921), 1. 212.

${ }^{63}$ Pechatnik 12 (Nov. 7, 1923): 11; Moskovskii pechatnik 34 (Dec. 1924): 14; ibid. 35 (Dec. 20, 1924): 11; ibid. 5 (Feb. 8, 1925): 12; ibid. 25 (July 1, 1925): 12; ibid. 28 (July 21, 1925): 9; TsGAMO, f. 699, op. 1, d. 849 (factory meetings at the Sixteenth Print Shop, Moscow, 1926), 1. 176; Moskovskii pechatnik 16 (April 1926): 7; ibid. 4748 (Dec. 5, 1925): 4. At the Zinov'ev printshop in Leningrad, "production deviations" of youth included absenteeism, tardiness, violation of professional discipline, and drinking (Zorkii glaz [Jan. 22, 1927]). A similar litany of misbehavior was cited in the union journal in 1930 (Pechatnik 1 [January 1930]: 2).

${ }^{64}$ Moskovskii pechatnik 8 (March 1, 1925): 13.

${ }^{65}$ Stenograficheskii otchet $V S^{\prime \prime}$ ezda (1924), p. 80.

${ }^{66}$ GARF, f. 5525, op. 11, d. 17 (protocols of the printers' union central committee presidium, 1929), 1. 159.

${ }^{67}$ Moskovskii pechatnik 14 (Dec. 10, 1923): 16; ibid. 8 (June 16, 1923): 19; Nasha zhizn' (Oct. 11, 1923), p. 2; Pechatnyi dvor (Aug. 31, 1929). 
March of the Young Printers

We are young printers ... and about us

The chatty typesetters tell this tale:

How we arrive from the unemployment office,

Too lazy to work.

But we try for real work again-yes, we do.

Chorus:

So teach us, instructor, don't just swear at us!

We have declared war on the calamity of red tape,

Let's whip and lash all loafers and idlers.

We will fight with them with our pens but not swords. ${ }^{68}$

Invoking the anthem of the victorious civil war along with the antibureaucratic language of socialist transformation, these lyricists attempted to define and to justify a worthy place for themselves within the socialist order. The song appealed for tolerance and inclusion, but it also asserted a militancy and sense of entitlement.

Other young printers complained that adults objected to young workers' inclusion in factory commissions, including the factory committees on which they had reserved spots. To adults' arguments that juveniles only interfered with the good order of the enterprise, the young printers countered that their inability to work properly in these committees should not be blamed on the young, but rather on the enterprises' poor organization — red tape again. Youth were naturally boisterous and noisy, but this should not provoke disciplinary measures. And youth had their own material grievances: the extremely low pay and increasingly slim job prospects as compensation for their years of training. ${ }^{69}$

Once we move beyond the bland proceedings of official congresses, then, the picture of relations between apprentices and adult skilled workers reveals a polarized landscape of tension and hostility. Few intermediate layers of identity, such as marital status or seniority, seemed to soften the sharp chasm between adults and youth, at least rhetorically. Male adult workers appeared to regard young workers as annoying, bothersome, and unwelcome. How much was this due to economic pressure? How much was a cultural aversion? Economic tension was considerable, as the expenses involved in supporting the less-productive apprentices could be seen to affect directly the material wellbeing of the adult males. When a group of young pressmen decided to organize a model work site, they were opposed by workers who grumbled that "the young want to sing their own praises and to take the bread out of the mouths

${ }^{68}$ Zorkii glaz (March 20, 1925).

${ }^{69}$ Pechatnik 4 (March 1923): 37; Moskovskii pechatnik 4 (Jan. 28, 1925): 15; ibid. 28 (July 21, 1925): 9. 
of the adults." ${ }^{70}$ But youth were also perceived as alien: they spoke a different jargon and failed to respect established rules of precedence. Badly trained apprentices, and potentially all apprentices, cast doubt on the competence, the manliness of adult printers. Male printers' hostility to sharing their work space with women was often expressed in terms of skill: skill was something men could possess, the ability to earn a skilled wage was a marker of masculinity. Women could therefore never become skilled. ${ }^{71}$ The years of apprenticeship were also recalled in hues of feminized subordination: masters beat their apprentices like they did their wives; apprentices minded the owners' children, helped the cook in the kitchen, and even milked the cow. Only the acquisition of skill-completion of the apprenticeship-permitted them to leave these womanly roles behind and to become men. ${ }^{72}$

The scarcity of openings for young printers must surely have produced other kinds of conflicts, not just between generations and sexes but also among families, further eroding the basis for "class" loyalty and class identity. Adult printers may have resented the upstarts and the challengers to their jobs, but they may have resented the youth more generally as competitors to their own offspring, not to themselves. ${ }^{73}$ The trade union tried at first to steer children of printers away from following in their fathers' footsteps. It was "medieval" and "not rational" for fathers to pass on their trades to their sons: printers' children had inherited their fathers' weaknesses and diseases (such as tuberculosis), and training such youths would harm the future of the trade. ". "Scientific" replacement policy would choose apprentices based on aptitude and physical health, not family connections. Socialist generations would be reproduced by the collective, not by biological paternity.

Yet real fathers did want to secure a place for their children. ${ }^{75}$ When the selection of new apprentices for the 1924-25 year began, Moscow union officials received 1,300 applications for thirty spaces. The union established a central admission commission, which prioritized the petitions of second-generation printers based on the neediness of the family, in addition to the results of medical and literacy examinations. But within these limits, the union ruled

${ }^{70}$ Zorkii glaz (Feb. 23, 1929).

${ }^{71}$ This argument is developed more fully in Koenker, "Men against Women."

${ }^{72}$ Pavlov (n. 23 above), pp. 40-46; Pechatnik 18 (June 25, 1927): 21; Moskovskii pechatnik 17 (April 1926): 2.

${ }^{73}$ This was the reaction to "deskilling" in many industrialized locations: workers resisted not on their own behalf, but on behalf of their sons. See, e.g., Eric Hobsbawm, "The Making of the Working Class, 1870-1914," in Workers (New York, 1984).

${ }^{74}$ Pechatnik 7 (June 1923): 8. See also Baron (n. 20 above), p. 62, for similar conflict between heritable perquisites and scientific selection of printing apprentices.

${ }^{75}$ TsGAMO, f. 699 , op. 1, d. 438, 1.28 (petition of a worker to secure a place for his son: factory committee minutes, Dec. 3, 1923). 
that 70 percent of the new recruits to an enterprise's FZU school should be children of workers of that enterprise-honoring the workers' own demand to pass on their trades, collectively if not personally, as an inheritance to their sons (and daughters). ${ }^{76}$ If all youths were "others," some were more alien than the rest.

Such complaints about the lack of opportunities for apprentices disappeared completely and suddenly only at the end of 1929 and the beginning of 1930, when the expanding economy finally escalated the demand for the products of the printing industry. Young workers lost their identity as the economic competitors of early years: indeed, due to the reduction of apprenticeship during the past six years, there were now hardly any young workers at all, a scarcity exacerbated by the frequency with which all workers could abandon one job or training site for better conditions or pay elsewhere. ${ }^{77}$ Continuing adjustment of training programs to produce quickly trained but narrow specialists received high priority in union discussions. ${ }^{78}$

The representation of the young by the union leadership and in the union press, however, had already been changing: still rowdy (especially in their offwork activities), by the late 1920s youth began to be portrayed as the leading edge of a new industrial culture. As a part of its strategy to justify rapid industrialization through the use of the metaphor of renewed class war, the regime called upon its youth to rejoin the vanguard of the proletariat and to play a key role in the struggle against old ways, to shock the older generation of workers out of their complacent shop-floor culture. At the Eighth Komsomol Congress in May 1928, Nikolai Bukharin invited young activists to form brigades of "light cavalry" who would make lightning raids on factory and nonfactory institutions to uncover corruption and incompetence. ${ }^{79}$ The trade union called upon young workers to join "shock brigades" dedicated to raising their

\footnotetext{
${ }^{76}$ Of the rest, the union agreed that 20 percent should be youths from children's homes, and 10 percent from the labor exchange, which was supposed to be the source of first resort for new hires (Moskovskii pechatnik 45 [Nov. 15, 1925]: 10). Another variant reserved 60 percent of spots for children of trade union members, 20 percent from the children's homes, 10 percent from the exchange, and 10 percent by exchange with other unions (Pechatnik 17 [Sept. 1, 1925]: 13). For evidence that fathers found places for daughters as well as sons in their trade, see Nasha zhizn' (Dec. 1, 1923).

${ }^{77}$ The problem of letunstvo (flitters) emerged in the discussion in the December 1930 first joint congress of print and paper workers (after the merger of the two industrial unions), GARF f. 5525, op. 12, d. 1, 1. 105.

${ }^{78}$ Pechatnik 32-33 (Nov. 30, 1929): 5, 33; ibid. 35 (Dec. 15, 1929): 10; ibid. 36 (Dec. 25, 1929): 19; ibid. 3 (1930): 10-11; ibid. 4 (1930): 7; ibid. 6 (1930): 16; GARF, f. 5525, op. 12, d. 38 (second Leningrad oblast' congress, February 1930), 11. 12-13.

${ }^{79}$ Zhizn' pechatnika (Aug. 18, 1928). On the congress, see Fisher (n. 27 above), p. 158; and VIII Vsesoiuznyi s"ezd VLKSM, 5-16 maia 1928. Stenograficheskii otchet (Moscow, 1928), pp. 34-35, cited in Fisher.
} 
output and efficiency, but although the shock brigades constituted a new form of socialist industrial mobilization, this new development was part of a continuing effort to reinvigorate the production sphere through an endless series of campaigns such as production conferences, prizes to inventors, contests for best this and fastest that, and, most recently, "self-criticism."

Great emphasis was placed in 1928 on using the enthusiastic youth as the "light cavalry" to "add yeast" to the self-criticism project. ${ }^{81}$ Small detachments of young printers swept through factory committee and other offices seeking to uncover waste and mismanagement; to halt the sales of spirits; to prod the apprentice commission into action. ${ }^{82}$ Was this "real" or artificially spotlighted activism? The central printers' union press emphasized the renewed activism of youth, and Hiroaki Kuromiya, using similar kinds of central institutional sources, also argues that these movements "marked a 'consummation of all of the production initiatives' undertaken by the Komsomol in the previous few years." ${ }^{83}$ If this renewed activism was real, why did young workers respond more readily to regime appeals for participation in 1928 and 1929 than they had earlier in the decade? Because they had been so long shut out of production, and they were now retaliating against those who had oppressed, sneered at, and excluded them? Perhaps they responded at this time because they had in the meanwhile been developing their own sense of identity, away from the shop floor, through youth groups, their FZU schools, and clubs. Printers' unions in the United States worried that the goals of technical schools "were not simply to teach technical aspects of the work but to socialize pupils into a nonunion work culture." ${ }^{84}$ Craft patriotism had always been a hallmark of Russian printers even while they professed allegiance to ideals of class solidarity. Soviet printers' unions, whether Menshevik or Bolshevik, had fiercely defended the unique identity and privileges of the craft, in the face of regime assaults on such tsekhovshchina, or craft patriotism. ${ }^{85}$ In their exclusion from

${ }^{80}$ On the latter, see Chase (n. 1 above), p. 281; and for an early episode in contest mania, see Diane P. Koenker, "Factory Tales: Narratives of Industrial Relations in the Transition to NEP," Russian Review 55 (1996): 384-411. I address this phenomenon more systematically in my book in progress on the printers in the 1920s.

${ }^{81}$ Zhizn' pechatnika (Aug. 18, 1928).

${ }^{82}$ Pechatnik 33 (Nov. 23, 1928): 35; ibid. 34 (Dec. 5, 1928): 30-31; ibid. 4 (February 1930): 7 .

${ }^{83}$ Kuromiya, Stalin's Industrial Revolution, pp. 115-16; quote is from VI Vsesoiuznaia konferentsiia VLKSM, 17-24 iiunia 1929 g. Stenograficheskii otchet (Moscow, 1929), p. 349.

${ }^{84}$ Baron (n. 20 above), p. 65.

${ }^{85}$ Some of this is discussed in Diane P. Koenker, "Class and Consciousness in a Socialist Society: Workers in the Printing Trades during NEP," in Russia in the Era of NEP: Explorations in Soviet Culture and Society, ed. Sheila Fitzpatrick, Alexander Rabinowitch, and Richard Stites (Bloomington, Ind., 1991), pp. 34-57. 
this adult male shop culture, Russian adolescent workers may have developed a loyalty to the regime that diluted their loyalty to craft, a true class consciousness that could now be mobilized against the particularities of craft and the privileges of seniority. ${ }^{86}$ Given this scenario, the "cultural revolution" did indeed represent the revenge of the young against the old, retaliation for the persistence of generational discrimination.

But a careful reading of the factory-level sources strongly suggests that much of this activism was artificially highlighted-that it was an invention, more propaganda than agitation. The light cavalry unit at the First Model printshop, created in response to Bukharin's call in August 1928, was "stillborn" and needed to be revived in June 1929, with little reported activity thereafter. ${ }^{87}$ In Leningrad, light cavalries made cameo appearances at local printshops in 1929, but their artificiality was made clear in a note from the Leningrad Pravda shop in early 1930, which admitted that the unit existed at all only because Komsomol activists were forced to join. Only one exploit of the Pechatnyi Dvor printshop's light cavalry found its way into the shop's newspaper, a raid on a cooperative grocery store that uncovered a stock of frozen potatoes. A light cavalry unit at the Twenty-Sixth State shop emerged in response to Bukharin's call in April 1929 (nearly a year after the Komsomol congress) but had disappeared by November 1930 .

Of six factory newspapers I surveyed, only one reported substantial activism from the local light cavalry. The Krasnyi Proletarii unit in Moscow, created in January 1929, apparently conducted numerous raids, especially devoting its energies to locations outside the production process. State publishing house proofreaders, the factory canteen, the factory warehouse, the neighborhood police, cooperatives, and banks received the brunt of the unit's attention, in raids that evoke the image of "junior G-men" of twentieth-century American popular culture. These community locations might best attract the attentions of young activists seeking to wage class struggle, but the Krasnyi Proletarii activists also turned their vigilant eye to production, finding waste on the shop floor and monitoring the fulfillment of the five-year plan. ${ }^{88}$ The unusual zeal at this particular shop is best explained by the energy and enthusiasm of the leader of its light cavalry, an apprentice named Volodia Riadovoi, who dominated the unit's activities. Riadovoi, it turns out, had been expelled from the Komsomol in 1928 for his support of Lev Trotskii, and while he profusely

${ }^{86}$ For this argument, see Hiroaki Kuromiya, "The Crisis of Proletarian Identity in the Soviet Factory, 1928-1929," Slavic Review 44 (1985): 280-97.

${ }^{87}$ Zhizn' pechatnika (Aug. 18, 1928); ibid. (June 1, 1929); ibid. (Sept. 27, 1930).

${ }^{88}$ Reports on the light cavalry can be found in Krasnyi proletarii, Jan. 21, Feb. 5, Feb. 13, May 30, June 22, Sept. 1, Oct. 11, Nov. 7, Nov. 25, 1929; Jan. 25, April 12, May 29, July 10, Sept. 17, 1930. 
apologized for his poor political judgment and had perhaps organized the light cavalry in order to atone for his error, he may just as well have used the light cavalry as an ideologically correct cover for his continuing oppositional activity. ${ }^{89}$ The local Komsomol itself stood aloof from the light cavalry at Krasnyi Proletarii. One of the cavalry's accusations concerned the censor at the State Publishing House, who was blamed for excessive waste by refusing to allow the publication of books once they had been set and printed: the example given was a work by the Menshevik economist and memoirist N. N. Sukhanov. ${ }^{90}$ Here indeed was danger from a generation incubating the wrong political values.

Far more common, however, than reports on light cavalries or youth shock brigades was the incessant harping at youth for their lack of political activism, for "empty" shock brigades, indifference toward meetings, lack of concern for production, for too much concern for private instead of production life, and for dancing instead of defending the Soviet Union. ${ }^{91}$ "We are seeking," read one satiric classified notice in Krasnyi Proletarii, "lost consciousness about the goals and tasks of the Komsomol. Please reply to the Komsomol cell, attention: some conscious Komsomols." ${ }^{92}$ In some cases, such complaints about youth inactivism explicitly invoked the language of generation. Komsomols sought any excuse to avoid meetings. They slacked off on work as well, and they remained indifferent to campaigns to reduce production losses. What kind of next generation was this? "These are the next generation" of socialism, but "they are silent." ${ }^{93}$ And who alone was vocal? Trotskyists! Trotskyists and other oppositionists symbolized for party regulars - adult menthe continuing danger of losing control of the next generation, and the continuing danger as well as the possibilities of youth in general. Even if conflicts on the shop floor translated not so much into resistance as political passivity, here was a real danger for the socialist project, for the goals of the trade union as mobilization agent of the working class.

The problem of youth could also be its solution, at least for males: generations, by definition, succeeded one another. Boys wanted to become men. But what kind of men? The Komsomol organization aimed to instill the proper socialist and political values among the plastic younger generation, but membership in the Komsomol also stamped a younger worker as subordinate, inferior, and incomplete. The Komsomol, like apprenticeship, symbolized the

${ }^{89}$ Riadovoi's apology was printed in Krasnyi proletarii (March 9, 1929).

${ }^{90}$ Krasnyi proletarii (May 18, 1929).

${ }^{91}$ Iskry (Dec. 20, 1930) on empty brigades; the other charges are endemic in the factory press throughout the 1920 s and do not lose their intensity in the years from 1928 to 1930 , when youth activism was allegedly on the rise.

${ }^{92}$ Krasnyi proletarii (Feb. 15, 1927).

${ }^{93}$ Krasnyi proletarii (March 24, 1928); ibid. (June 20, 1930). 
dependence of youth. Young printers thus chafed at the categories of subordination created for them by the dual institutions of apprenticeship and the Young Communist League. This is one way to explain the wave of Komsomol resignations reported at the end of this period. Once an apprentice had finished his or her training and had become skilled, he or she no longer wanted to play a role in the Komsomol either. ${ }^{94}$ The newly fledged worker cast behind the official role of "activist youth" in favor of building a private life, a family life. Marusia Perchuk had been a Komsomol member for two years, but as soon as she finished her apprenticeship and became an "individual person" [odin iz liudei] she resigned from the Komsomol and pursued parties and dancing until dawn. ${ }^{95}$ After Tolia Abramov graduated from the factory apprentice school, this five-year Komsomol member became more interested in football and drinking than in Komsomol meetings, and he asked to be permitted to resign. ${ }^{96}$ Young workers linked their Komsomol membership with their years of occupational subordination, and once the labor market opened up new possibilities for them they left their Komsomol badges behind, formally resigning from the generation of the constructors of communism. These young adults wanted to get on with their lives, not with the revolution.

This experience of generational conflict and of youthful political apathy, while based on a case study of one Russian industry, is not unique to the printers, despite their self-consciously distinctive brand of working-class culture. First, the customs and rituals of the acquisition of skills - the humiliation of apprentices, their incorporation into the community of work-were typical of many skilled trades, as numerous scholars have attested $\cdot{ }^{97}$ Second, the kind of antagonism between the older generation and the young Soviet generation has been reported elsewhere in Soviet industry in the 1920s. In the textile industry, Chris Ward notes trade union reports that "workers were 'indifferent' to youngsters, there should be some "stimulus' to encourage them." The textile union journal featured a story in 1926 about a master who refused to impart his skills to a young worker. ${ }^{98}$ Third, evidence about the activism of youth

${ }^{94}$ Pechatnyi dvor (April 27, 1929); ibid. (Aug. 1, 1930); Krasnyi proletarii (May 1, 1928); Zhizn' pechatnika (Jan. 21, 1930); Pechatnyi dvor (April 27, 1929); Leningradskii pravdist (April 12, 1930); ibid. (April 30, 1930).

${ }_{95}^{95}$ Leningradskii pravdist (Nov. 23, 1930).

${ }^{96}$ Iskry (Aug. 23, 1929).

${ }^{97}$ Among others, see Victoria E. Bonnell, Roots of Rebellion: Workers' Politics and Organizations in St. Petersburg and Moscow, 1900-1914 (Berkeley, Calif., 1983), pp. 64-65; Laura Engelstein, Moscow, 1905: Working-Class Organization and Political Conflict (Stanford, Calif., 1982), p. 28; Diane Koenker, Moscow Workers and the 1917 Revolution (Princeton, N.J., 1981), p. 66; Phillips (n. 17 above).

${ }^{98}$ Chris Ward, Russia's Cotton Workers and the New Economic Policy: Shop-Floor Culture and State Policy 1921-1929 (Cambridge, 1990), pp. 98-99. Chase also reports tension over the generational issue (n. 1 above), p. 152. 
involvement in shock brigades and the light cavalry tends to come from central institutional sources and from the memoirs of some of the activist veterans. The shop-floor experience not only in the printing industry but also in the Moscow machine-building plant studied by Kenneth Straus challenges the extent of much of this attributed activism. And, as Anne Gorsuch has recently pointed out, the Komsomol itself attracted barely half of eligible workers in Moscow and 62 percent in Leningrad. ${ }^{99}$

Concerns about hooliganism in the society at large also suggest that this phenomenon affected much more than the elite printing industry. The Borshchevskii FZU school was not the only producer of first-class hooligans. As Gorsuch has also illustrated, an anxiety about hooliganism in the late 1920s reflected the failure of youth to play their assigned role in the annals of political activism. ${ }^{100}$ "Hooliganism" meant drinking, fighting, and rude language: all of these had been part of the world of the male worker before the revolution, but now these energies were to be channeled more constructively, toward building socialism. The increase in concern about hooliganism in the second half of the 1920 s focused primarily on the young, who most regularly frequented workers' clubs and who appeared to reject the sober values of the socialist elite. The Moscow printers' union journal reported on the trial of five young (all aged twenty-one or twenty-two) typesetters, "hooligans" who had been arrested for terrorizing a crowd and injuring a militiaman in the city center. Their defense was to claim they had been so drunk they did not know what they were doing. "Hooligans" at the communal apartment house of one print shop yelled and whistled in the hallways and stairwells, played the accordion, swore a blue streak in front of children and young women at the playground, and ended up playing cards and drinking beer and vodka, becoming too hung over to go to work the next day. ${ }^{101}$ The wages of hooliganism became manifest when a young printer, twice expelled from the Komsomol for hooliganism, fighting,

${ }^{99}$ On Komsomol shock brigades, see Kuromiya, Stalin's Industrial Revolution, pp. 110-11; Lewis H. Siegelbaum, Stakhanovism and the Politics of Productivity in the USSR 1935-1941 (Cambridge, 1988), p. 43; Kenneth M. Straus, Factory and Community in Stalin's Russia: The Making of an Industrial Working Class (Pittsburgh, 1997), pp. 136-39; Gorsuch, Youth in Revolutionary Russia, p. 188. David R. Shearer's account of Komsomol activism in production focuses on young engineers rather than products of the factory apprentice system (Industry, State, and Society in Stalin's Russia, 1926-1934 [Ithaca, N.Y., 1996]). See also Peter Gooderham, "The Komsomol and Worker Youth: The Inculcation of 'Communist Values' in Leningrad during NEP," Soviet Studies 34 (1982): 506-28; and Vladimir Brovkin, Russia after Lenin: Politics, Culture, and Society 1921-1929 (London, 1998), chap. 5. The evidence Brovkin adduces, however, is not sufficient to support his categorical statement that "manifest avoidance of 'politics' was itself a political act" (p. 122).

${ }^{100}$ Gorsuch, Youth in Revolutionary Russia, pp. 167-76.

${ }^{101}$ Moskovskii pechatnik 40-41 (October 1926): 5. 
and other crimes, ran amok when he was laid off and wounded two fellow workers, one fatally. Workers at the shop called for him to be charged with the crime of malicious hooliganism, to receive the "highest form of punishment," that is, the death penalty. ${ }^{102}$ Hooliganism resulted when youth knew their rights but not their responsibilities, a refrain that echoed complaints from adult workers on the shop floor as well. Thus some youths may have been active, but not in ways that would advance the socialist project.

$$
* * *
$$

Youth were segregated and treated as a special category in the socialist Russian work space. The construction of this category developed in part from the ideological premises of the modernizing socialist regime, but the separation and incorporation of youth were also based on the experience of work and daily life in the period. The importance of economic conjuncture cannot be underestimated. The economic conditions of the industry forced young workers out of the workplace and deprived them of an opportunity to develop a sense of identity based on their place in production alongside adult males. The economic competition for scarce jobs pitted youth against adults. Yes, all things being equal, it was a fine thing to divert social resources toward the allaround training and general education of youth in a production setting. But the fragile economic health of this industry (and the socialist urban economy more generally in the NEP period) reinforced a culture of inequality that favored adult males over juveniles as well as women. Adult males, in the union and in the party, retained control of entry into the trade, creating resentment and resistance, hooliganism, maybe, but not political rebellion. Youth could afford to wait until they were no longer juveniles, especially under conditions of economic growth. ${ }^{103}$

Rather than adopting policies to benefit society as a whole, the printers' union in practice dealt with these inequalities in a more personalistic and, one might argue, paternalistic way. In the case of the training of both women and youths, the interests of rational labor training and distribution became subordinated to the interests of families as fathers sought to place their own children in the scarce work spots, and as union members more broadly argued for allocating places according to family need. Official priority in hiring apprentices was given to children from large families, and priority in layoffs went to families with two or more adult wage earners. ${ }^{104}$ The family remained, in the socialist economy, a basic unit of economic optimization.

102 Pechatnik 9 (March 25, 1927): 11.

${ }^{103}$ Gorsuch reports a survey of Moscow workers' children in 1927 in which only 19 percent wished to become workers themselves (Youth in Revolutionary Russia, p. 39).

${ }^{104}$ See the discussion on "doubles" (dvoiniki) in Koenker, "Men against Women," 
What was the effect, though, of the years of marginalization on the culture of youth? When young people did return to the labor force in strength at the beginning of the 1930s, they may have brought with them a culture and a set of values that were based less on the experience of production, where they had been treated as inferiors, than on the identities they had developed outside production: the "hooligan" world of the club and the street, the "socialist" world of education and upward mobility. The exclusion and subordination of youth in production, despite an official productivist ideology, denied them a role in the prevailing shop-floor culture. But the regime encouraged young workers to dream about their futures as socialist citizens, not just as workers. Was it not part of the socialist vision of the New Person, in fact, that the new identity of socialist youth would derive from their nonproduction lives in schools and evening classes, in clubs, in youth dormitories, and, less propitiously, from the streets? ${ }^{105}$ Ironically, then, as the great push for industrial production gathered force in 1929 and 1930, the very values of work and productivism that had been a key element of the Bolshevik vision of their future ten years before now faced competition from a very different set of values, centered on everyday life (byt) rather than production. That this transformation in working-class culture was occurring elsewhere in the industrial world at the same time probably provided little comfort to Bolshevik builders who saw their factory dreams threatened by lipstick, the tango, and doublebreasted suits. ${ }^{106}$

Trade union policy did not manage to solve the dual problem of generations and of generational conflict in the workplace. Generations retained their dual character. As the engine of transformation, the youth-as-constructor-of-communism model provided the union with the rationale for its proactive policies toward youth in the workplace. Throughout this period, the trade union maintained its belief in a model of continuity of generations. But the older model of "fathers and sons," embedded in Russian culture since Ivan Turgenev's 1862 novel Fathers and Sons, also exerted an important influence on behavior in the workplace. Generations also competed.

pp. 1457-60. The preference for kin-based hiring was also evident in the textile industry (Ward [n. 98 above], pp. 100-102).

${ }^{105}$ Mentions of a youth consumer culture can be found in Zhizn' pechatnika (Nov. 7, 1923), and ibid. (March 1, 1924). See also John Hatch, "Hangouts and Hangovers: State, Class, and Culture in Moscow's Workers' Club Movement, 1925-1928," Russian Review 53 (1994): 97-117; Gorsuch, Youth in Revolutionary Russia, chap. 6; Anne E. Gorsuch, "Soviet Youth and the Politics of Popular Culture during NEP," Social History 17 (1992): 189-201.

${ }^{106}$ Lizabeth Cohen, Making a New Deal: Industrial Workers in Chicago, 1919-1939 (New York, 1991); Kathy Peiss, Cheap Amusements: Working Women and Leisure in New York City, 1880-1920 (Philadelphia, 1986). 
The experience of young workers at the end of the 1920s suggests an additional model of generations. Generations were not only an engine for social progress, as one generation replaced another in orderly fashion, over and over again, whether four-year generations of factory apprentices or more conventional twenty- or thirty-year demographic generations making the journey from birth to maturity. Following the work of Karl Mannheim, I would also emphasize that some generations represented unique cohorts, whose distinctiveness was triggered by the conjunction of the social and cultural process of their formative years. ${ }^{107}$ The 1917 revolution and civil war imbued that generation of young workers with a commitment to socialism and to class warfare. ${ }^{108}$ Likewise, the factory generation or two that grew to adulthood in the straitened circumstances of the stagnant years of NEP may have brought with them an alienation from production plus a sense of entitlement that translated into poor work ethics and a taste for consumerism. Whose values and what experience would shape the next generation? The trade union regime itself, in constructing youth as a demographic generational category, ignored the effect of unique cohorts, of generational units, and kept struggling with its ideologically conditioned bifurcated view of heroic youth as constructors of communism or hooligan youth who required iron discipline to keep them toeing the production line. Thus the union could continue to publicize a nonexistent political activism of youth, an activism that was an integral part of the regime's very conception of any generation of youth, however far from social reality.

The category of youth as constructed in Soviet practice thus possessed an ambivalence and ambiguity that did not fit with Soviet class-based ideas about identity and solidarity. Soviet trade unionists and socialist planners, therefore, minimized discussion of both generational and gender conflict on the shop floor and insisted instead that the key source of discord in the socialist workplace was the "class" conflict between proletarians and peasants, a dichotomy that continues to dominate some current interpretations of Soviet working-

${ }^{107}$ Mannheim (n. 4 above), p. 310.

${ }^{108}$ This argument about young workers in 1917 is developed in Diane Koenker, "Urban Families, Working-Class Youth Groups, and the 1917 Revolution in Moscow," in The Family in Imperial Russia: New Lines of Historical Research, ed. David L. Ransel (Urbana, Ill., 1978), pp. 280-304. The effect of generational experience can also be seen in the life of Eduard Dune, a young communist of the 1917 generation who never lost his commitment to socialism, however critical he had become of or victimized by the Stalin regime; see Eduard M. Dune, Notes of a Red Guard, ed. and trans. Diane P. Koenker and S. A. Smith (Urbana, Ill., 1993). See Detlev J. K. Peukert, "Alltagsleben und Generationserfahrungen von Jugendlichen in der Zwischenkriegszeit," in Dowe, ed. (n. 3 above), pp. 139-50; Sheila Fitzpatrick, "The Civil War as a Formative Experience," in Bolshevik Culture: Experiment and Order in the Russian Revolution, ed. Abbott Gleason, Peter Kenez, and Richard Stites (Bloomington, Ind., 1985), pp. 57-76. 


\section{Koenker}

class formation. ${ }^{109}$ Certainly the differences in culture and attitudes between city and countryside were important, but they should not be allowed to overshadow other sources of schism and discord in the socialist workplace.

The adult male trade unionist world of the Soviet workplace has come to assume a "natural" place as a standard of the working class. Even this male trade union culture was riven by political and cultural disagreements, by conflicting attitudes toward youth and toward women. Men did speak out on behalf of the next generation and for raising up women. Nor were the voices of youth or women monolithic, however rigidly the regime sought to construct these categories. But these categorizations-like the construction of nations-contributed to their very formation, groups defined in everyday discourse that served as the focus of conflict and discord. Conflicts between generations and between genders on the socialist shop floor, and the reactions to them, helped to structure daily life and production life, contributing to attitudes and expectations that would surely remain an integral part of socialist culture- the marginalizing of youth and of women-in the developing process of socialist industrialization.

${ }^{109}$ Kuromiya, Stalin's Industrial Revolution, esp. chap. 4; David L. Hoffmann, Peasant Metropolis: Social Identities in Moscow, 1929-1941 (Ithaca, N.Y., 1994). Chris Ward (n. 98 above) offers a compelling refutation of this binary paradigm. 